ISSN 0258-7122

Bangladesh J. Agril. Res. 38(1): 97-104, March 2013

\title{
ADAPTABILITY OF WHEAT VARIETIES IN STRONGLY ACIDIC SOILS OF SYLHET
}

\author{
M. ATAUR RAHMAN ${ }^{1}$, N. C. D. BARMA ${ }^{1}$, M. H. SARKER ${ }^{2}$ \\ M. M. R. SARKER ${ }^{3}$ AND M. M. I. NAZRUL ${ }^{3}$
}

\begin{abstract}
A field trail was carried out at South-Surma, Sylhet, in 2009-10 and at FSRD site Jalalpur, Sylhet in 2010-11 in collaboration with WRC and OFRD, BARI to examine the response of 7 wheat varieties at two levels of lime in split-plot design where lime was applied in main plots and different wheat varieties were grown in sub-plots. The seeds were sown on 05 December 2009 and 30 November 2010 for the growing season of 2009-10 and 2010-11, respectively. The wheat varieties used in this study were Shatabdi, Sufi, Sourav, Bijoy, Prodip, BARI Gom-25 and BARI Gom-26. The index of relative performance of each variety in comparison to mean yield of all varieties under the contrast conditions of liming and non-liming was estimated to determine relative adaptability of wheat variety under experimental soil conditions. The result indicated that most of the yield components viz., spikes $/ \mathrm{m}^{2}, 100$-grain weight, and grain yield of wheat were significantly improved by liming for both the years and locations. There were variations in lime response among the wheat varieties. The index of relative adaptability (IRA \%) for yield of BARI Gom-26 and Bijoy was more than $100 \%$ for both the years. The results indicated that these two wheat varieties are relatively tolerant to low $\mathrm{pH}$ and could be adapted in acidic soil of Sylhet.
\end{abstract}

Keyword: Low pH tolerant wheat variety, soil acidity, wheat adaptability.

\section{Introduction}

Acidic soil is wide-spread in Bangladesh. The soils of entire hill region, Modhupur tract, High-level Barind area, and the soils of entire Sylhet region are strongly acidic. The chemical analysis of these soils suggests that the soils are grossly deficient in $\mathrm{P}, \mathrm{Ca}$, and $\mathrm{Mg}$, low in CEC with higher levels of exchangeable iron and aluminum at the surface. Several experiments and trials (Rahman et al., 2000; Rahman et al., 2002, and Rahman et al., 2004) demonstrated the beneficial effect of liming and suggested lime recommendation in such an acidic soil in north-west Bangladesh under rice-wheat cropping system. Liming increases the availability of $\mathrm{P}$ and decreases the toxic availability of $\mathrm{Fe}, \mathrm{Mn}$, and $\mathrm{Al}$, thus ensures the balance of most of the plant nutrients resulting higher crop productivity (Stood and Bhardwaj, 1992; Rahman et al.,

\footnotetext{
${ }^{1}$ Regional Wheat research Centre, Bangladesh Agricultural Research Institute (BARI), Gazipur, ${ }^{2}$ Farm Division, BARI, Gazipur, ${ }^{3}$ On-farm Research Division, BARI, Sylhet, Bangladesh.
} 
2004). Several other reports Mongia et al., 1998; Rahman et al., 2000; Rahman et al., 2002, and Rahman et al., 2004) also suggest that liming eliminated the toxic effect of aluminum and manganese and increased the availability of several plant nutrients, such as $\mathrm{Ca}, \mathrm{Mg}, \mathrm{P}, \mathrm{N}$, and Mo. Thus lime application improved crop yield by eliminating the production constraints and favouring production factors related to nutrient availability (Rahman et al., 2005). Though liming is recommended as an important tool for the amendment of acidic soil, it involves high production cost at the beginning of crop production and, therefore, difficult for the marginal growers to explore the benefit of liming. Thus an alternate approach of varietal intervention might be useful for the expansion of wheat cultivation in acidic soil. Wheat varieties identified as relatively non-responsive to liming might be considered as adaptable in acidic soil and those varieties could be promoted in acidic regions. Therefore, this trial was initiated to identify wheat varieties adaptable in acidic soil of Sylhet for the expansion of wheat cultivation in Sylhet region where vast land usually remains fallow after harvesting paddy rice in the winter.

\section{Method and Materials}

A field trial was conducted at farm level in south-Surma, Sylhet and FSRD site Jalalpur for the two consecutive wheat seasons of 2009-10 and 2010-11 to find out the wheat varieties suitable for the acidic soil of Sylhet region. Both the experimental soils are characterized by non-Calcareous Grey Floodplains under the textural class of silty clay loam. The soils were under the major land type of medium low land and strong acidic in soil reaction. Soil $\mathrm{pH}$ and nutrient contents of native soils before imposing the liming treatments are presented in Table 1 . The surface soil $\mathrm{pH}$ was lower than subsurface that might be due to leaching of base elements leaving the higher levels of iron and aluminum oxides at the surface as indicated by higher levels of $\mathrm{Fe}$ and $\mathrm{Al}$ in initial soil samples. Soils of both the locations are deficient in several plant nutrients such as $\mathrm{N}, \mathrm{P}, \mathrm{K}, \mathrm{Ca}$, and $\mathrm{Mg}$, but the available $\mathrm{Zn}$ and $\mathrm{B}$ contents are above the critical limits. The liming material used in the experiment was called Dolo Chun, which was finely ground white powder with effective calcium oxide equivalent of $48 \%$ and the material was rich in several plant nutrients including $\mathrm{Mn}$ and $\mathrm{B}$ but was free from $\mathrm{P}$ and Zn (Table 2). Crop response of seven wheat varieties namely Shatabdi, Sufi, Sourav, Bijoy, Prodip, BARI Gom-25 and BARI Gom-26 were examined at two levels of lime (2.0 t/ha that raise soil $\mathrm{pH}$ near 6.0 and control) in split-plot design where lime was applied in main plots and wheat varieties were grown in subplots. Lime was applied and incorporated into the soil two weeks before sowing wheat. The wheat seeds were sown on 05 December 2009 for the first year and on 30 November 2010 for the second year. Fertilizers at the rates of $100 \mathrm{~kg}$ N, 30 
$\mathrm{kg} \mathrm{P}, 50 \mathrm{~kg} \mathrm{~K}$ and $20 \mathrm{~kg} \mathrm{~S} / \mathrm{ha}$ were applied as urea, triple super phosphate, muriate of potash, and gypsum, respectively. All fertilizers including two-thirds urea were uniformly applied in the field during final land preparation. The rest of the urea was topdressed at the crown root initiation (CRI) stage at 21 days after sowing (DAS). The crop was irrigated thrice to bring the soil moisture near to the field capacity during CRI, booting, and grain-filling stages. Weeds were controlled once at 30 DAS manually by hand weeding. During maturity, crops were harvested duly and sun-dried then the dried crop was threshed and the grains were dried in the atmosphere, then grain yields were converted to $t / h a$ at $12 \%$ moisture content.

To compare the varietal adaptability, an index of relative adaptability (IRA\%) for yield and yield components were estimated following the equation below: adapted from Fisher and Maurer (1978)

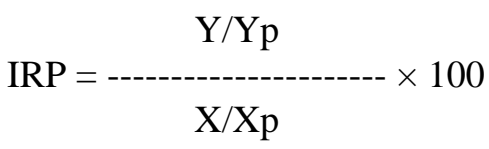

Y: Yield of a genotype under non-liming

Yp: Yield of same genotype under liming

$\mathrm{X}$ : Mean yield of all genotype under non-liming

$\mathrm{Xp}$ : Mean yield of all genotype under liming

All data were statistically analyzed and the mean values were tested by the least significant difference (LSD) at 5\% level of significance.

Table 1. Chemical properties and available plant nutrient content in soils at two locations before initiation of the experiment.

\begin{tabular}{|c|c|c|c|c|c|c|c|c|c|}
\hline \multirow{2}{*}{$\begin{array}{l}\text { Depth } \\
\text { (cm) }\end{array}$} & $\mathrm{pH}$ & $\mathrm{P}$ & $\mathrm{K}$ & $\mathrm{Ca}$ & $\mathrm{Mg}$ & $\mathrm{Zn}$ & $\mathrm{B}$ & $\mathrm{Fe}$ & $\mathrm{Al}$ \\
\hline & \multicolumn{9}{|c|}{$\mathrm{mg} / \mathrm{kg}$ soil } \\
\hline \multicolumn{10}{|c|}{ South Surma } \\
\hline $0-15$ & 4.8 & 6.6 & 16.8 & 68.8 & 18.8 & 0.75 & 0.214 & 178.4 & 54.4 \\
\hline $15-30$ & 5.3 & 5.7 & 12.4 & 58.6 & 14.5 & 0.81 & 0.117 & 131.1 & 28.6 \\
\hline \multicolumn{10}{|c|}{ Jalalpur } \\
\hline $0-15$ & 4.6 & 5.9 & 13.7 & 82.5 & 20.2 & 0.66 & 0.158 & 144.5 & 58.2 \\
\hline $15-30$ & 5.5 & 5.2 & 11.2 & 87.2 & 14.7 & 0.82 & 0.122 & 112.2 & 35.5 \\
\hline
\end{tabular}

Table 2. Chemical composition and neutralizing ability of the liming material used in the experiments.

\begin{tabular}{c|c|c|c|c|c|c|c|c}
\hline $\begin{array}{c}\mathrm{Ca} 0 \\
\text { equivalent } \\
(\%)\end{array}$ & $\mathrm{Ca}$ & $\mathrm{Mg}$ & $\mathrm{K}$ & $\mathrm{Na}$ & $\mathrm{P}$ & $\mathrm{Zn}$ & $\mathrm{Mn}$ & $\mathrm{B}$ \\
\cline { 2 - 10 } & \multicolumn{9}{c}{$(\%)$} & \multicolumn{5}{c}{$\mathrm{mg} / \mathrm{kg}$} \\
\hline 48 & 20.1 & 7.2 & 0.18 & 0.32 & 0 & 0 & 44 & 62.4 \\
\hline
\end{tabular}




\section{Results and Discussion}

\section{a) Main effect of liming}

All the yield components of wheat viz., number of spikes $/ \mathrm{m}^{2}$, grains/spike, 1000grain weight and grain yield significantly responded to liming in both the years and locations (Table 3 - 6). The soil of both the locations were strongly acidic (Table 1) and lime application in such a soil increased soil $\mathrm{pH}$ resulting increase in nutrient availability and thereby favoured plant growth and tillering of wheat (Rahman et al., 2002). Thus the lime induced higher plant growth and more tiller formation might contribute to higher spikes $/ \mathrm{m}^{2}$ compared to non-limed plots. Generally root growth is restricted in low $\mathrm{pH}$ soil due to iron and aluminum toxicity, but lime application in such a soil make the soil environment favourable for root growth of wheat by reducing the toxicity of $\mathrm{Fe}$ and $\mathrm{Al}$ (Rahman et al., 2005). Plant nutrient uptake and its translocation from source to sink largely depend on chemical environment of soil, which is favourable under lime application (Rahman et al., 2005). Thus the grain size of wheat was improved as indicated by higher TGW under liming compared to non-liming. Also the plants under liming had higher grains/spike compared to non-liming. Though the particular role of liming in increasing grains/spike is not clear, the higher nutrient availability and favourable soil condition may contribute to higher number of fertile spikelets and thereby contribute to higher grains/spike. Thus by eliminating the plant growth constraints and favoring the production factors liming resulted the higher wheat yield that was attributed to higher spikes $/ \mathrm{m}^{2}$, grains/spike and 1000-grain weight of wheat.

Table 3. Effect of liming on number of spikes plant ${ }^{-1}$ and grains/spike of different wheat varieties at acidic soil of Sylhet 2009-10.

\begin{tabular}{l|llllll}
\hline \multirow{2}{*}{ Varieties } & \multicolumn{3}{c}{${\text { Spikes } / \mathrm{m}^{2}}$} & \multicolumn{3}{c}{ Grains/spike } \\
\cline { 2 - 7 } & With lime & No lime & IRP (\%) & With lime & No lime & IRP (\%) \\
\hline Shatabdi & 331.2 & 312.8 & 105.2 & 37.5 & 33.9 & 96.3 \\
Bijoy & 328.5 & 316.2 & 105.8 & 38.8 & 37.6 & 102.0 \\
Sourav & 327.9 & 289.5 & 97.0 & 34.8 & 32.8 & 99.2 \\
Sufi & 319.7 & 268.8 & 92.4 & 46.5 & 45.2 & 102.3 \\
Prodip & 309.8 & 257.8 & 91.4 & 36.5 & 34.1 & 98.3 \\
BARI Gom-25 & 311.6 & 277.6 & 97.9 & 40.8 & 36.6 & 94.4 \\
BARI Gom-26 & 323.6 & 298.5 & 101.4 & 42.1 & 39.7 & 99.3 \\
\hline Mean & 321.8 & 288.7 & & 39.6 & 37.1 & \\
CV (\%) & 9.7 & & & 7.8 & & \\
LSD(0.05) & & & & & & \\
Column-wise & 24.1 & & - & Ns & & - \\
Among rows & Ns & 22.4 & & 3.3 & 3.2 & \\
\hline
\end{tabular}


Table 4. Effect of liming on thousand grain weight and yield of different wheat varieties at acidic soil of Sylhet 2009-10.

\begin{tabular}{|c|c|c|c|c|c|c|}
\hline \multirow[b]{2}{*}{ Varieties } & \multicolumn{3}{|c|}{ 1000-grain weight } & \multicolumn{3}{|c|}{ Grains yield (t/ha) } \\
\hline & With lime & No lime & IRP (\%) & With lime & No lime & IRP (\%) \\
\hline Shatabdi & 48.2 & 43.7 & 97.2 & 4.56 & 3.62 & 93.86 \\
\hline Bijoy & 46.2 & 44.3 & 103.1 & 4.24 & 3.82 & 105.99 \\
\hline Sourav & 48.7 & 44.5 & 98.3 & 4.19 & 3.56 & 99.96 \\
\hline Sufi & 37 & 34.2 & 99.4 & 3.65 & 3.03 & 97.66 \\
\hline Prodip & 51.2 & 47.2 & 99.1 & 4.2 & 3.32 & 93.00 \\
\hline BARI Gom-25 & 46.4 & 42.8 & 99.2 & 4.24 & 3.62 & 100.44 \\
\hline BARI Gom-26 & 49.2 & 48.2 & 105.3 & 4.42 & 3.98 & 105.94 \\
\hline Mean & 46.7 & 43.6 & & 4.21 & 3.56 & \\
\hline CV (\%) & 8.7 & & & 10.2 & & \\
\hline $\operatorname{LSD}(0.05)$ & & & & & & \\
\hline Column-wise & 3.1 & & - & 0.36 & & - \\
\hline Among rows & 3.5 & 3.4 & & 0.40 & & \\
\hline
\end{tabular}

Table 5. Effect of liming on number of spikes/plant and grains/spike of different wheat varieties at acidic soil of Sylhet 2010-11.

\begin{tabular}{|c|c|c|c|c|c|c|}
\hline \multirow[b]{2}{*}{ Varieties } & \multicolumn{3}{|c|}{ Spikes $/ \mathrm{m}^{2}$} & \multicolumn{3}{|c|}{ Grains/spike } \\
\hline & $\begin{array}{l}\text { With } \\
\text { lime }\end{array}$ & No lime & $\begin{array}{l}\text { IRP } \\
(\%)\end{array}$ & With lime & $\begin{array}{l}\text { No } \\
\text { lime }\end{array}$ & $\begin{array}{l}\text { IRP } \\
\text { (\%) }\end{array}$ \\
\hline Shatabdi & 309.7 & 274.7 & 99.2 & 35.7 & 32.8 & 98.6 \\
\hline Bijoy & 291.7 & 279.8 & 107.0 & 35.2 & 32.9 & 98.4 \\
\hline Sourav & 287.7 & 251.3 & 97.7 & 39.4 & 35.8 & 95.6 \\
\hline Sufi & 314.7 & 273.3 & 96.4 & 46.4 & 45.1 & 102.3 \\
\hline Prodip & 315 & 274 & 97.1 & 37.4 & 34.3 & 96.5 \\
\hline BARI Gom-25 & 317 & 278.7 & 97.8 & 38.8 & 35.8 & 97.1 \\
\hline BARI Gom-26 & 327.2 & 304.9 & 104.4 & 39.7 & 37.2 & 98.6 \\
\hline Mean & 309 & 276.7 & & 38.9 & 36.3 & \\
\hline CV (\%) & 10.5 & & & 8.1 & & \\
\hline \multicolumn{7}{|l|}{$\operatorname{LSD}(0.05)$} \\
\hline Column-wise & 27.2 & & - & Ns & & - \\
\hline Among rows & Ns & 20.7 & & 3.1 & 2.9 & \\
\hline
\end{tabular}


Table 6. Effect of liming on thousand grain weight and yield of different wheat varieties at acidic soil of Sylhet 2010-11.

\begin{tabular}{|c|c|c|c|c|c|c|}
\hline \multirow[b]{2}{*}{ Varieties } & \multicolumn{3}{|c|}{ 1000-grain weight } & \multicolumn{3}{|c|}{ Grains yield (t/ha) } \\
\hline & $\begin{array}{l}\text { With } \\
\text { lime }\end{array}$ & No lime & IRP (\%) & $\begin{array}{l}\text { With } \\
\text { lime }\end{array}$ & No lime & IRP (\%) \\
\hline Shatabdi & 47.8 & 44.1 & 99.5 & 3.98 & 3.32 & 96.8 \\
\hline Bijoy & 47.6 & 46.5 & 105.0 & 4.01 & 3.6 & 102.0 \\
\hline Sourav & 47.9 & 41.7 & 93.6 & 4.14 & 3.63 & 99.6 \\
\hline Sufi & 38.7 & 35.5 & 98.6 & 3.82 & 3.13 & 93.1 \\
\hline Prodip & 52.8 & 48.1 & 98.0 & 4.39 & 3.64 & 94.2 \\
\hline BARI Gom-25 & 47.3 & 44.2 & 100.5 & 4.06 & 3.46 & 96.8 \\
\hline BARI Gom-26 & 51.8 & 49.4 & 102.5 & 4.42 & 4.06 & 104.4 \\
\hline Mean & 47.7 & 44.2 & & 3.98 & 3.32 & \\
\hline CV (\%) & 7.6 & & & 9.4 & & \\
\hline $\operatorname{LSD}(0.05)$ & & & & & & \\
\hline Column-wise & 3.3 & & & 0.41 & & \\
\hline Among rows & 3.2 & 3.0 & & 0.39 & 0.35 & \\
\hline
\end{tabular}

\section{b) Varietal response and adaptability}

Grain yield of wheat significantly varied due to varietal difference under lime application or without lime application for both the years though the yield differences due to variety were higher with lime compared to without lime (Table 4 and 6). Wheat yield ranged from 3.65 to $4.56 \mathrm{t} / \mathrm{ha}$ and 3.82 to $4.42 \mathrm{t} / \mathrm{ha}$, respectively, in 2009-10 and 2010-11 under liming, whereas under no-liming yield ranged from 3.03 to 3.98 t/ha and 3.13 to 4.06 t/ha, respectively, in 2009-10 and 2010-11. The variety Sufi produced significantly higher grains/spike than all other varieties in non-limed soil for both the years. The same variety also produced higher grains/spike under limed soil which was statistically similar to BARI Gom-26 and BARI Gom-25. On the contrary, 1000-grain weight (TGW) of the variety Sufi was the minimum both for liming and non-liming conditions. TGW was the maximum in Prodip followed by that of BARI Gom-26 in both the years under limed soil conditions, but the variety Prodip could not exhibit higher IRP (Index of relative performance) in TGW. The estimated index of relative adaptability (IRA\%) in TGW was the maximum in BARI Gom-26 and Bijoy, respectively, for the years 2009-10 and 2010-11. IRA (\%) in yield of different wheat varieties ranged from 93 to $106 \%$ and 93.1 to $104.4 \%$, respectively, in 2009-10 and 2010-11. The wheat varieties Bijoy and BARI Gom-26 showed similar higher values of IRP (\%) that was above $100 \%$. The result indicated that these two wheat varieties are comparatively adaptable in experimental soil conditions. Like grain yield, spikes $/ \mathrm{m}^{2}$, and 1000-grain weight varied and the wheat varieties those had higher IRA (\%) for yield were also gave better IRA for spikes $/ \mathrm{m}^{2}$ and 1000 -grain weight. The exception result was found in case of IRA 
for grains/spike, where the maximum IRA was observed in Sufi. Sufi produced maximum grains/spike and even under non-lime condition grains/spike of Sufi was higher than average grains/spike of all varieties under liming (Table 3 and 5). However, this varietal advantage of Sufi failed to contribute to higher grain yield due to poor performance of other yield components like spike $/ \mathrm{m}^{2}$ and 1000 grain weight. IRP for spikes $/ \mathrm{m}^{2}$ was the maximum in variety Bijoy followed by Shatabdi in 2009-10 and Bijoy also performed the best result in IRP followed by BARI Gom-26 in 2010-11. IRA for thousand grain weight was the maximum in BARI Gom-26 and Bijoy, respectively, for 2010-11 and 2009-10. The value of IRA (\%) for yield was above 100 for variety of Bijoy and BARI Gom-26 for both the years. Whereas the values IRA for yield of other 6 wheat varieties were less than 100. Thus, the result indicated that Bijoy and BARI Gom-26 have the potentials to be adapted under the experimental soil conditions of low $\mathrm{pH}$. These two wheat varieties could be promoted for the expansion of wheat production in Sylhet region.

\section{References}

Chang C. S. and J. M. Sung. 2004. Nutrient uptake and yield responses of peanuts and rice to lime and fused magnesium phosphate in an acid soil. Field Crops Res. 89: 319-325.

Fisher, R. A., and R. Maurer. 1978. Drought resistance in spring wheat cultivars. I. Grain yield responses. Aust. J. Agric. Res. 29: 897-907.

Rahman, M. A., M. Bodruzzaman, A. J. M. S. Karim, M. A Razzaque and C. A. Meisner. 2000. Effect of lime and phosphorus on soil $\mathrm{pH}$, available $\mathrm{P}$ in soil and yield of wheat in acid soil of Dinajpur. Annals of Bangladesh Agric. 10(2): 125-131.

Rahman, M. A., C. A. Meisner, J. M. Duxbury, J. G. Lauren and A. B. S. Hossain. 2001. Yield response and change in nutrient availability by application of lime, fertilizer and micronutrients in acidic soil within a rice-wheat cropping system. Bangladesh $J$. of Agril.. Res. 26(3): 357-365.

Rahman, M. A., C. A. Meisner, J. M. Duxbury, J. Lauren and A. B. S. Hossain. 2002: Integrated approach of liming and nutrient management to improve the productivity of acidic soil within a rice-wheat cropping system. Poster no. 773, Symposium no. 05, $17^{\text {th }}$ World Congress of Soil Science. 14-21 August 2002. Bangkok, Thailand.

Rahman, M. A., J. Chikushi, J. G. Lauren, J. M. Duxbury and C. A. Meisner. 2004: Liming and nutrient management for sustainable productivity of acidic alluvial soils under rice-wheat cropping system in Bangladesh. Proc. $6^{\text {th }}$ International symposium on plant-soil interaction at low pH. pp. 304-305. August 1-5, 2004. Sendai, Japan. Organized by International steering committee on Soil-Plant Interaction at low $\mathrm{pH}$.

Rahman, M. A., J. Chikushi, J. G. Lauren, J. M. Duxbury, C. A. Meisner, and E. Yasunaga. 2005. Chemical control of soil environment by lime and nutrients to 
improve the productivity of acidic alluvial soils under rice-wheat cropping system. Environmental Control in Biology 43(4): 259-266.

Mongia, A. D., N. T. Singh, L. N. Mandal, and A. Guha. 1998. Effect of liming, superphosphate and rock phosphate application to rice on the yield and uptake of nutrients on acid sulphate soils. J. Indian Soc. Soil Sci. 46: 61-66

Stood, R. D. and R. K. Bhardwaj. 1992. Effect of liming and phosphorus fertilization on the P fractions in an acid Alfisol. J. Indian Soc. Soil Sci. 40: 299-301.

Tang, C., Z. Rengel, E. Diatloff and C. Gazey. 2003. Response wheat and barley to liming on sandy soil with subsoil acidity. Field Crops Res. 80: 235-244. 